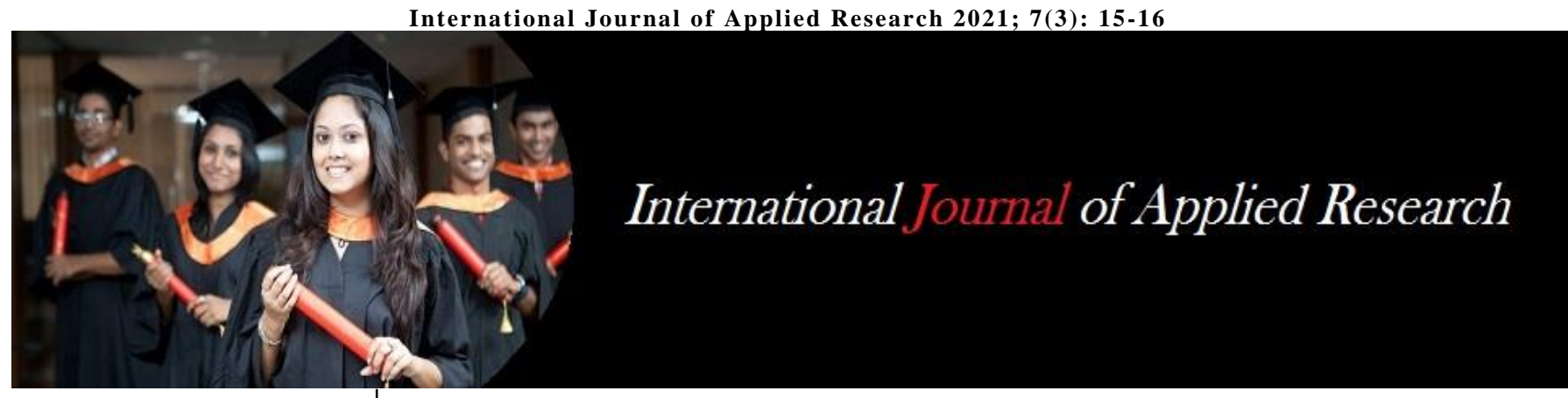

ISSN Print: 2394-7500 ISSN Online: 2394-5869 Impact Factor: 8.4

IJAR 2021; 7(3): 15-16 www.allresearchjournal.com

Received: 10-01-2021

Accepted: 12-02-2021

Runumi Sharma

Ph.D. Scholar, Department of Education, S.S.J. University, Almora, Uttarakhand, India

Deepesh Sharma

Ph.D. Scholar, Department of Veterinary Parasitology,

C.V.A. \& Sc., G.B.P.U.A.\&T., Pantnagar, Uttarakhand, India
Corresponding Author: Runumi Sharma Ph.D. Scholar, Department of Education, S.S.J. University, Almora, Uttarakhand, India

\section{Digital learning for enhancing learning experience}

\section{Runumi Sharma and Deepesh Sharma}

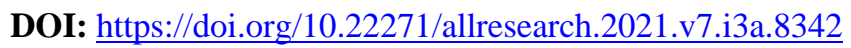

\section{Abstract}

Information and Communication Technology (I.C.T.) has brought changes in all sectors including education. It is the I.C.T. which is responsible for bringing quality, innovation and excellence in education. In education sector, I.C.T. encourages digital learning. Digital learning is learning through digital devices such as mobile phones, laptops and computers etc. There are various digital tools which are used to impart education to make the educational process interesting and effective. The study is based on literature study method and observation. This paper deals with describing digital tools and their advantages as well as disadvantages. It is truth that despite the disadvantages, the digital tools in education has revolutionized the educational process. In this competitive world it is important for the children to be aware of digital learning so that they will take the advantages of digital learning.

Keywords: digital tools, digital learning, I.C.T.

\section{Introduction}

It is the world where we cannot imagine a life without I.C.T. I.C.T. influences all sectors including education. I.C.T. is part of modern education system and there is involvement of I.C.T. in our current teaching process (Anderson, 2005) ${ }^{[1]}$. I.C.T. plays a major role in providing quality of education to students. Our life has been influenced by I.C.T. from morning to night. Learning through I.C.T. is known as e-learning. Appropriate use of I.C.T. can transformed the whole teaching learning processes leading to paradigm shift in both content and teaching methodology (Sharma et al., 2011) ${ }^{[6]}$. I.C.T. plays a major role in improving the quality of education. It works as an assisting tool. Several initiatives were taken by Government of India for providing quality material for educational purposes in digital forms like Multimedia Educational Resource for Learning an Online Teaching (MERLOT) and National Program of Technology Enhanced Learning (NPTEL) (Patra, 2014) ${ }^{[5]}$. I.C.T. has changed the way the student learned from content centered form of curriculum to competency based curriculum and shifted from teacher centered process to student centered process (Yousuf et al., 2013) ${ }^{[7]}$. Digital learning is the use of technology in the learning process to enhance the learning of students. There are various digital tools which help in enhancing learning experience. It is important for the teachers to be efficient in using digital devices so that they can make the teaching effective and interesting. The document prepared by Ministry of Education accepted "teacher performance is the most crucial input in the field of education" (G.O.I., 1985) ${ }^{[3]}$. It is the digital learning which has positive influence over student's growth, understanding and achievement (Cathy, 2010) ${ }^{[2]}$. Teachers use various strategies such as blended learning, personalize learning and flipped learning that make use of digital tools for making the learning effective. There is growth in use of digital tools in present day classroom. Students are fully aware of using the internet, smart phones and computers. In this highly digital world teachers need to keep pace with the technological advancement. The use of digital tool in the classroom makes an environment for better experience and learning. It is important to bring changes in education sector with the change in technology. The technological advancement helps many universities to offer online courses to reach the unreached (Zhang, 2011) ${ }^{[8]}$. 


\section{Digital tools in education}

Digital learning is a learning in which technology is used in the form of digital tools for making the learning effective. There are various digital tools which are used for making the learning effective. Digital tools are type of hardware or software that can be used in the field of education (Mahiri, 2011) ${ }^{[4]}$. The various digital tools are Google Classroom, You tube Channel, Blogs, Discussion boards, Wikis, Class Dojo, Edmodo, Socrative, Edublogs, Prezi and 3-D Virtual Worlds. These digital tools are helpful for both teachers and students. Students can ask questions and teachers can give answers to students with the help of these tools. Teachers can share learning materials through these digital tools. Teachers can use these digital tools for assessment and grading of students. In this technological world, there is paradigm shift in the teaching learning process, where the technology plays a major role. Teachers need to adjust themselves with these changes so that learning experience of students can be enhanced. There are various advantages and disadvantages of digital tools.

\section{Advantages of using digital tools in digital learning}

This is a modern era, where technology is used in every sector including education. If you are not tech-savvy in this highly competitive world then, it become tough to survive in this competitive world. The use of technology in education has some advantages and risks too. The advantages of using digital tools in education are as follows:

1) The use of digital tools helps the hearing impaired children to learn effectively.

2) The use of digital tools enhances learning of students.

3) Learning through digital tools makes the learning interesting and effective.

4) The use of digital tools helps to record the lectures. This helps student to watch the recorded lectures when they miss the lectures and want to clear their doubt.

5) The use of digital tools in learning helps to get familiar with the technology.

6) The use of digital tools helps the student to prepare for the real world. It increases the employability of students.

7) The use of digital tools in digital learning helps in the better knowledge retention.

8) The use of digital tools in education help the students to participate in online activities where they can collaborate with others.

\section{Disadvantages of using digital tools in digital learning}

We enjoy the advantages of digital tools in digital learning but, there are many disadvantages of digital tools in the field of education.

1) The use of digital tools in digital learning can distract students. They use digital tools for their enjoyment instead of paying attention to the learning experience.

2) The use of digital tools in digital learning disconnects the face to face relationship between teacher and students.

3) It is not possible that all children can access to digital tools. This causes a gap between have's and have not's.

4) The overuse of digital tools can cause health problems in children such as eyes strain and headache. They may develop severe problem of "computer vision syndrome" and "early myopia".
5) There may be misuse of technology by students. It has negative effect on students. They start playing games in mobiles or computers in the name of study.

6) The use of digital tools in education requires proper management by school authorities. It becomes expensive.

\section{Conclusion}

In the world of new technologies teachers are adopting digital learning for better learning by students. The digital tools in education are helpful for providing freedom to students, for encouraging collaboration and for better assessment. Though there are many disadvantages of digital tools in education but, we cannot deny the positive influence of digital tools in the life of children.

\section{References}

1. Anderson J. I.T., e-learning and teacher development, International Education Journal, 2005;5(5):1-14.

2. Cathy S. "CD-ROM, Story books and young readers". Tech Trends- August, 2010.

3. G.O.I. Challenge of Education: A Policy perspective. Ministry of Education, Government of India 1985.

4. Mahiri J. Digital tools in urban school: Mediating a remix of learning. Ann Arbor: University of Michigan Press 2011.

5. Patra, JN. The Role of I.C.T. in improving the quality of school education in India. International Educational E-Journal. 2014; 3(2):152-156.

6. Sharma A, Gandhar K, Seema. Role of I.C.T. in the process of teaching and learning. Journal of Education and Practice. 2011;2(5):1-6.

7. Yousuf MA, Afloabi FO, Losto AB. Appraising the role of information communication technology as a change agent for higher education in Nigeria International Journal of Educational Administration and Policy Studies 2013;5(8):177-183.

8. Zhang $\mathrm{Y}$. The design and realization of multimedia courseware for university photography foundation, IEEE Transactions, July 2011. 